\title{
Reduction of ${ }^{68} \mathrm{Ge}$ activity containing liquid waste from ${ }^{68} \mathrm{Ga}$ PET chemistry in nuclear medicine and radiopharmacy by solidification
}

\author{
Erik de Blois • Ho Sze Chan • Kamalika Roy • \\ Eric P. Krenning $\cdot$ Wouter A. P. Breeman
}

Received: 29 October 2010/Published online: 23 December 2010

(C) The Author(s) 2010. This article is published with open access at Springerlink.com

\begin{abstract}
PET with ${ }^{68} \mathrm{Ga}$ from the $\mathrm{TiO}_{2}$ - or $\mathrm{SnO}_{2}$ - based ${ }^{68} \mathrm{Ge} /{ }^{68} \mathrm{Ga}$ generators is of increasing interest for PET imaging in nuclear medicine. In general, radionuclidic purity $\left({ }^{68} \mathrm{Ge}\right.$ vs. ${ }^{68} \mathrm{Ga}$ activity) of the eluate of these generators varies between 0.01 and $0.001 \%$. Liquid waste containing low amounts of ${ }^{68} \mathrm{Ge}$ activity is produced by eluting the ${ }^{68} \mathrm{Ge} /{ }^{68} \mathrm{Ga}$ generators and residues from PET chemistry. Since clearance level of ${ }^{68} \mathrm{Ge}$ activity in waste may not exceed $10 \mathrm{~Bq} / \mathrm{g}$, as stated by European Directive 96/29/EURATOM, our purpose was to reduce ${ }^{68} \mathrm{Ge}$ activity in solution from $>10 \mathrm{kBq} / \mathrm{g}$ to $<10 \mathrm{~Bq} / \mathrm{g}$; which implies the solution can be discarded as regular waste. Most efficient method to reduce the ${ }^{68} \mathrm{Ge}$ activity is by sorption of $\mathrm{TiO}_{2}$ or $\mathrm{Fe}_{2} \mathrm{O}_{3}$ and subsequent centrifugation. The required $10 \mathrm{~Bq}$ per mL level of ${ }^{68} \mathrm{Ge}$ activity in waste was reached by $\mathrm{Fe}_{2} \mathrm{O}_{3}$ logarithmically, whereas with $\mathrm{TiO}_{2}$ asymptotically. The procedure with $\mathrm{Fe}_{2} \mathrm{O}_{3}$ eliminates $\geq 90 \%$ of the ${ }^{68} \mathrm{Ge}$ activity per treatment. Eventually, to simplify the processing a recirculation system was used to investigate ${ }^{68} \mathrm{Ge}$ activity sorption on $\mathrm{TiO}_{2}, \mathrm{Fe}_{2} \mathrm{O}_{3}$ or Zeolite. Zeolite was introduced for its high sorption at low $\mathrm{pH}$, therefore ${ }^{68} \mathrm{Ge}$ activity containing waste could directly be used without further interventions. ${ }^{68} \mathrm{Ge}$ activity containing liquid waste at different $\mathrm{HCl}$ concentrations $(0.05-1.0 \mathrm{M}$ $\mathrm{HCl}$ ), was recirculated at $1 \mathrm{~mL} / \mathrm{min}$. With Zeolite in the recirculation system, ${ }^{68} \mathrm{Ge}$ activity showed highest sorption.
\end{abstract}

E. de Blois · H. S. Chan · E. P. Krenning ·

W. A. P. Breeman $(\bowtie)$

Department of Nuclear Medicine, Erasmus MC,

's Gravendijkwal 230, 3015 Rotterdam, The Netherlands

e-mail: w.a.p.breeman@erasmusmc.nl

K. Roy

Department of Chemistry, University of Calcutta, Kolkata, India
Keywords ${ }^{68} \mathrm{Ge} \cdot$ Waste $\cdot$ Sorbent $\cdot$ Generator

\section{Introduction}

PET scintigraphy with ${ }^{68}$ Ga-labelled peptides is of increasing interest in PET imaging in nuclear medicine [1-8] and performed at $>40$ centres in Europe (current situation, 2010). In general, radionuclidic purity (RNP) of the eluate of these generators varies between 0.01 and $0.001 \%\left({ }^{68} \mathrm{Ge}\right.$ vs. ${ }^{68} \mathrm{Ga}$ activity). Liquid waste containing low amounts of ${ }^{68} \mathrm{Ge}$ activity (further referred as ${ }^{68} \mathrm{Ge}$ waste) is produced by eluting the ${ }^{68} \mathrm{Ge} /{ }^{68} \mathrm{Ga}$ generators and residues from PET chemistry. For several reasons in our facility, solid ${ }^{68} \mathrm{Ge}$ containing waste $(\mathrm{t} 1 / 2=9$ months) is preferred over liquid waste. Since clearance level of ${ }^{68} \mathrm{Ge}$ activity in waste may not exceed $10 \mathrm{~Bq} / \mathrm{g}$, as stated by European Directive 96/29/EURATOM, our aim was to reduce ${ }^{68} \mathrm{Ge}$ activity in solution from $>10 \mathrm{kBq} / \mathrm{g}$ to $<10 \mathrm{~Bq} / \mathrm{g}$; which implies the solution can be discarded as regular waste. As an example: when a $1,110 \mathrm{MBq}{ }^{68} \mathrm{Ge} /{ }^{68} \mathrm{Ga}$ generator with a RNP of $0.005 \%$, is eluted with $6 \mathrm{~mL} 1 \mathrm{M}$ $\mathrm{HCl}$, the eluate contains $55.5 \mathrm{kBq}{ }^{68} \mathrm{Ge}$ activity. Eluting a $1,110 \mathrm{MBq}{ }^{68} \mathrm{Ge} /{ }^{68} \mathrm{Ga}$ generator three times a day, 200 days per year, and for 1 year will result in $33.3 \mathrm{MBq}$ in $3.6 \mathrm{~L}(9.25 \mathrm{kBq} / \mathrm{g})$. Although national legislation within the EU may vary per country, the rules may only be more strict. For example in our country, The Netherlands, legislation does not allow to store radioactive waste with half-lives of more than 100 days at local institutes for more than 2 years. After 2 years it is obligatory to store the here described waste in a special external waste facility, and at additional costs. In this facility waste is preferably compressed, therefore, liquid content is limited to $<1 \%(\mathrm{v} / \mathrm{w})$. The purpose of this study was to quantify ${ }^{68} \mathrm{Ge}$ activity in our ${ }^{68} \mathrm{Ge}$ 
liquid waste, and to concentrate and to transform ${ }^{68} \mathrm{Ge}$ liquid waste to solid waste. In short: ${ }^{68} \mathrm{Ge}_{\text {liquid }} \Rightarrow{ }^{68} \mathrm{Ge}_{\text {solid }}$, initially on a small scale. Liquid ${ }^{68} \mathrm{Ge}$ waste was transformed to ${ }^{68} \mathrm{Ge}$ solid waste by sorption of $\mathrm{TiO}_{2}, \mathrm{Fe}_{2} \mathrm{O}_{3}(325$ and 500 mesh, respectively, Sigma-Aldrich, Zwijndrecht, The Netherlands) and Zeolite $\left(\mathrm{Na}_{2} \mathrm{Al}_{2} \mathrm{Si}_{3} \mathrm{O}_{10} \cdot 2 \mathrm{H}_{2} \mathrm{O}\right.$, Zeolyst international, Conshohocken, PA, USA). Elution of ${ }^{68} \mathrm{Ge} / \mathrm{Ga}$ generator is performed with $\mathrm{HCl}$, therefore ${ }^{68} \mathrm{Ge}$ waste is acidic. Zeolite was investigated because high sorption at low pH could be achieved (manuscript Kamalika Roy submitted).

\section{Experimental}

${ }^{68} \mathrm{Ge}$-containing liquid waste

Fractionated elution of the generator revealed at the activity of ${ }^{68} \mathrm{Ge}$ (eg. Bq per $\mathrm{mL}$ ) was constant during elution, whereas the main ${ }^{68} \mathrm{Ga}$ activity could be collected in a small volume $(1 \mathrm{~mL})$ [1]. Eluate from generators and left-over after ion-exchange prior radiolabelling is acidic and contain a certain amount of ${ }^{68} \mathrm{Ge}$ activity $[4,8]$. Quantification of ${ }^{68} \mathrm{Ge}$ activity was performed in a welltype gamma counter as described earlier [1]. During 5 years of daily practice with $4 \mathrm{TiO}_{2^{-}}$and $4 \mathrm{SnO}_{2}$-based ${ }^{68} \mathrm{Ge} /{ }^{68} \mathrm{Ga}$ generators $(0.4-2 \mathrm{GBq}$ per generator) the total amount of ${ }^{68} \mathrm{Ge}$ activity was $160 \mathrm{MBq}$ in $48 \mathrm{~L}$.

$\mathrm{TiO}_{2}$ and $\mathrm{Fe}_{2} \mathrm{O}_{3}$ as sorbent

Sorption of ${ }^{68} \mathrm{Ge}$ activity on variable amounts of $\mathrm{TiO}_{2}$ and $\mathrm{Fe}_{2} \mathrm{O}_{3}$ was investigated with $1 \mathrm{~mL}$ samples of ${ }^{68} \mathrm{Ge}$ waste as $f[\mathrm{pH}]$ (pH range 1-10) and time (range 1-24 h). These results were used for further up scaling. Typical example: $150 \mathrm{~mL}$ of ${ }^{68} \mathrm{Ge}$ waste was mixed with $\pm 1.5 \mathrm{~g}$ of $\mathrm{TiO}_{2}$ or $\mathrm{Fe}_{2} \mathrm{O}_{3}$ and centrifuged at $200 \times g$. One $\mathrm{mL}$ of supernatant was taken as a sample and ${ }^{68} \mathrm{Ge}$ activity was quantified $24 \mathrm{~h}$ after sampling as described earlier [1].

\section{Recirculation system}

Eventually, to simplify the processing of ${ }^{68} \mathrm{Ge}_{\text {liquid }} \Rightarrow$ ${ }^{68} \mathrm{Ge}_{\text {solid }}$ a recirculation system was used to investigate ${ }^{68} \mathrm{Ge}$ activity sorption (see Fig. 1) on $\mathrm{TiO}_{2}, \mathrm{Fe}_{2} \mathrm{O}_{3}$ and Zeolite. Eluate of ${ }^{68} \mathrm{Ge} / \mathrm{Ga}$ generator is acidic, therefore Zeolite was also investigated because high sorption at low $\mathrm{pH}$ could be achieved (Kamalika Roy manuscript submitted). ${ }^{68} \mathrm{Ge}$ waste at different $\mathrm{HCl}$ concentrations $(0.05-1 \mathrm{M}$ $\mathrm{HCl}$ ), was recirculated at $1 \mathrm{~mL} / \mathrm{min}$ and sorption of ${ }^{68} \mathrm{Ge}$ activity on $\mathrm{TiO}_{2}, \mathrm{Fe}_{2} \mathrm{O}_{3}$ or Zeolite was monitored timedependently. Recirculation system contained $\pm 1 \mathrm{~g}$ of

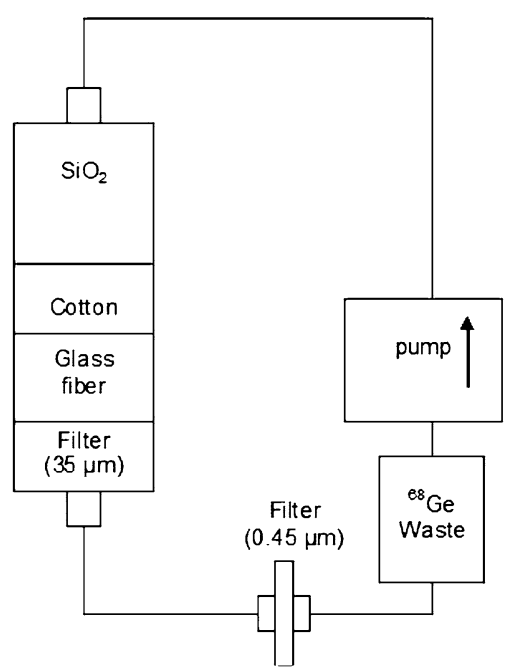

Fig. 1 Recirculation system containing $\pm 1 \mathrm{~g}$ of $\mathrm{TiO}_{2}, \mathrm{Fe}_{2} \mathrm{O}_{3}$ or Zeolite as sorption material enclosed with cotton, glass fiber and filters of 35 and $0.45 \mu \mathrm{m} .{ }^{68} \mathrm{Ge}$ activity containing waste was recirculated at a flow rate of $\pm 1 \mathrm{~mL} / \mathrm{min}$. Samples of the circulating liquid were taken at indicated time points (see also Figs. 5, 6)

sorption material enclosed with cotton, glass fiber and filters of 35 and $0.45 \mu \mathrm{m}$.

\section{Results and discussion}

Firstly, sorption on $\mathrm{TiO}_{2}, \mathrm{Fe}_{2} \mathrm{O}_{3}$ was investigated timedependently. Sorption of ${ }^{68} \mathrm{Ge}$ activity on $\mathrm{TiO}_{2}(0.5 \mathrm{~g} /$ $50 \mathrm{~mL}{ }^{68} \mathrm{Ge}$ waste) was low $(<20 \%)$ at $\mathrm{pH}<2$ and high $(>99 \%)$ at $\mathrm{pH}>6$ (Fig. 2). Sorption of ${ }^{68} \mathrm{Ge}$ activity on $\mathrm{Fe}_{2} \mathrm{O}_{3}\left(0.5 \mathrm{~g} / 50 \mathrm{~mL}{ }^{68} \mathrm{Ge}\right.$ waste $)$, showed better result at pH $1-3\left(>75 \% \mathrm{Fe}_{2} \mathrm{O}_{3}\right.$ and $\left.<25 \% \mathrm{TiO}_{2}\right)$ and increased also as $f[\mathrm{pH}]$ up to $>99 \%$ at $\mathrm{pH}$ 8. Optimal sorption was obtained at $\mathrm{pH} \geq 5$ (Fig. 2). Secondly sorption on $\mathrm{TiO}_{2}$, $\mathrm{Fe}_{2} \mathrm{O}_{3}$ was investigated as $f[$ mass] and additions of sorption

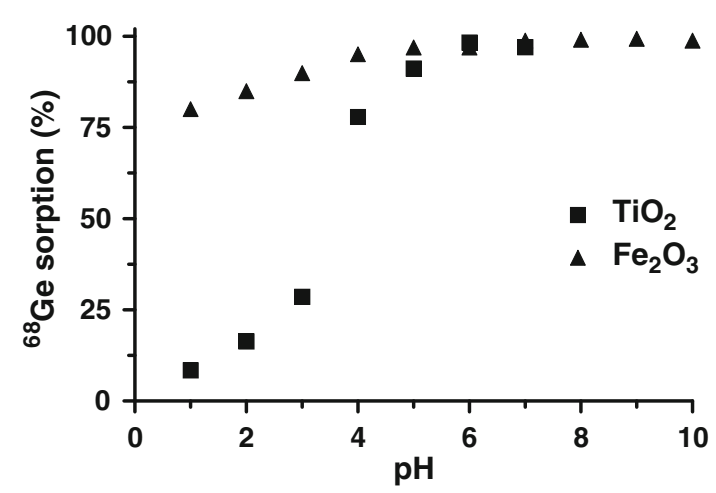

Fig. 2 Sorption of ${ }^{68} \mathrm{Ge}$ activity $(10 \mathrm{kBq} / \mathrm{g})$ on $\mathrm{Fe}_{2} \mathrm{O}_{3}$ or $\mathrm{TiO}_{2}$ was investigated as $f[\mathrm{pH}]$. After $24 \mathrm{~h}$ the samples were centrifuged. Supernatant was decanted and ${ }^{68} \mathrm{Ge}$ activity was quantified. Sorption of ${ }^{68} \mathrm{Ge}$ activity using $\mathrm{TiO}_{2}$ or $\mathrm{Fe}_{2} \mathrm{O}_{3}$ was optimal at $\mathrm{pH}>8$ 
material. Sorption of ${ }^{68} \mathrm{Ge}$ activity increased after each addition of sorption material. Moreover, $\mathrm{Fe}_{2} \mathrm{O}_{3}$ surprisingly continues to lower the ${ }^{68} \mathrm{Ge}$ activity logarithmically after each addition of $\mathrm{Fe}_{2} \mathrm{O}_{3}$, whereas with $\mathrm{TiO}_{2}$ the value of $10 \mathrm{~Bq}{ }^{68} \mathrm{Ge}$ per mL level was reached asymptotically. The procedure with $\mathrm{Fe}_{2} \mathrm{O}_{3}$ as sorption material reduces the ${ }^{68} \mathrm{Ge}$ activity by approximately $90 \%$ after each addition of

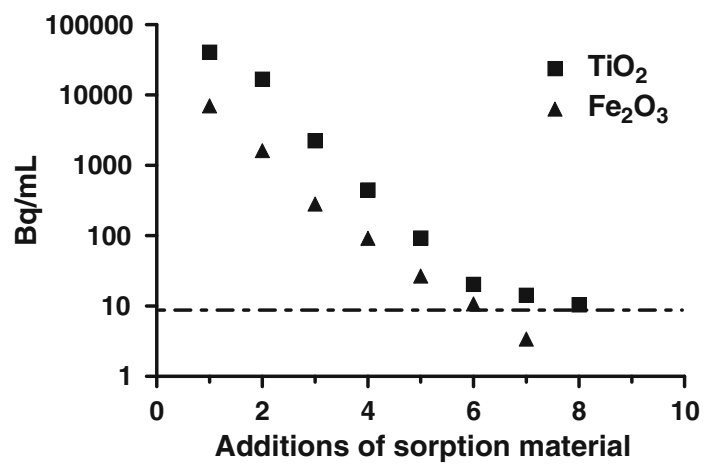

Fig. 3 Samples of ${ }^{68} \mathrm{Ge} /{ }^{68} \mathrm{Ga}$ generator eluate $(50 \mathrm{~mL})$ were used to investigate ${ }^{68} \mathrm{Ge}$ activity sorption on $0.5 \mathrm{~g} \mathrm{TiO}_{2}$ or $0.5 \mathrm{~g} \mathrm{Fe}_{2} \mathrm{O}_{3}$. pH of the eluate was controlled by addition of phosphate buffer, final $\mathrm{pH}$ was $\sim 8$, and gently vortexed. Twenty-four hours after each addition, the $50 \mathrm{~mL}$ was centrifuged and a sample of the supernatant was collected to quantify ${ }^{68} \mathrm{Ge}$ activity
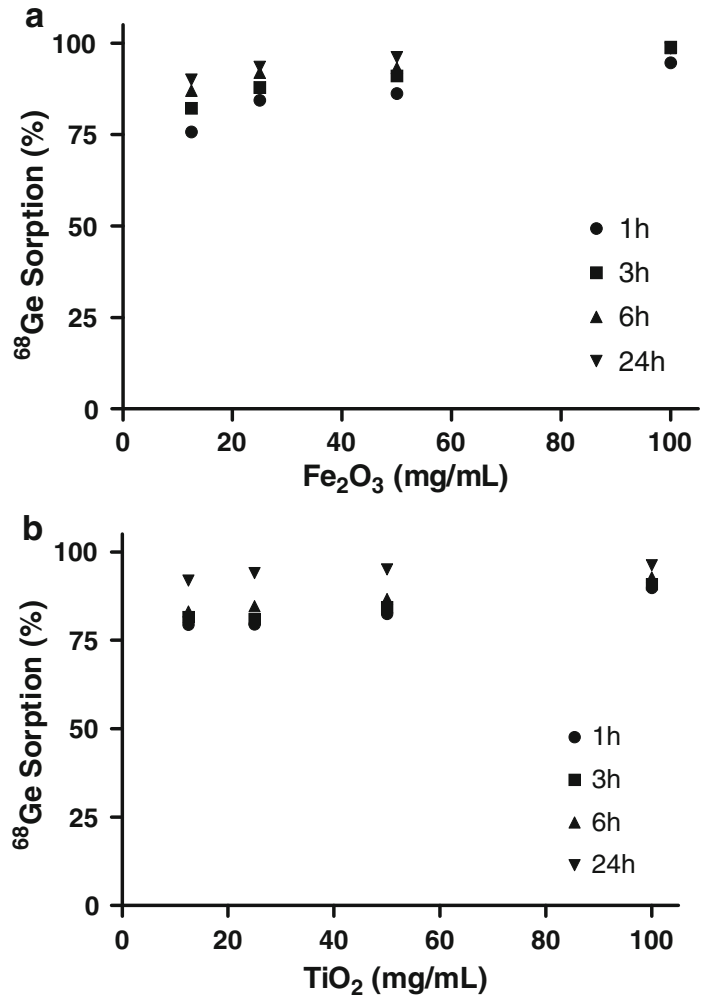

Fig. 4 Complexation of ${ }^{68} \mathrm{Ge}$ activity of ${ }^{68} \mathrm{Ge}$ containing liquid waste (pH 8) with $\mathrm{Fe}_{2} \mathrm{O}_{3}$ (a) or $\mathrm{TiO}_{2}$ (b) as sorbent as function of time $(1-24 \mathrm{~h})$ and mass of sorbent $(10-100 \mathrm{mg} / \mathrm{mL})$ sorption material (Fig. 3), eg. from $>10 \mathrm{kBq} / \mathrm{g}$ to $<10 \mathrm{~Bq} / \mathrm{g}$ in six procedures. Low amounts $(10 \mathrm{mg} / \mathrm{mL})$ of sorbent showed similar ${ }^{68} \mathrm{Ge}$ activity sorption at later time points in comparison with an amount of $100 \mathrm{mg} / \mathrm{mL}$ (Fig. 4a, b).

Zeolite was introduced since this has high sorption at low $\mathrm{pH}$, therefore it was tested as $f(\mathrm{pH})$ (Fig. 5). With Zeolite in the recirculation system (Fig. 1), ${ }^{68} \mathrm{Ge}$ waste (0.05-1.0 M HCl) showed highest sorption (Figs. 6, 7). In our facility, eluate purification and concentration with anion chromatography with $5 \mathrm{M} \mathrm{HCl}$ is also applied [4]. The waste stream is thus very acidic, but Zeolite as sorption material showed similar results as with $1 \mathrm{M} \mathrm{HCl}$ (Fig. 7). Summarized, recirculation system, using Zeolite as sorbent, is more efficient, less time consuming and reduces ${ }^{68} \mathrm{Ge}$ waste mass in comparison with $\mathrm{TiO}_{2}$ and $\mathrm{Fe}_{2} \mathrm{O}_{3}$ procedure. The overall ${ }^{68} \mathrm{Ge}$ containing liquid waste was $160 \mathrm{MBq}$ in $48 \mathrm{~L}$ and could be concentrated to $160 \mathrm{MBq}$ in $<1 \mathrm{~kg}$ solid waste.

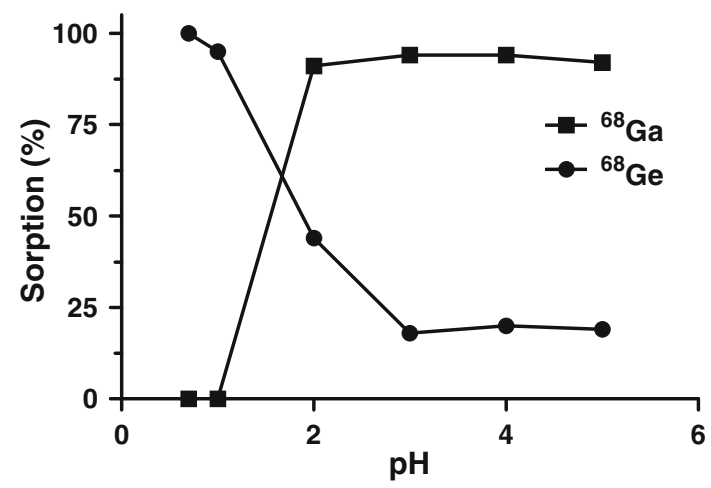

Fig. 5 Sorption of ${ }^{68} \mathrm{Ge}$ activity on Zeolite was investigated as $f[\mathrm{pH}]$. After $24 \mathrm{~h}$ the samples were centrifuged. Supernatant was decanted and ${ }^{68} \mathrm{Ge}$ activity was quantified. Sorption of ${ }^{68} \mathrm{Ge}$ activity using Zeolite was optimal at $\mathrm{pH}<1$

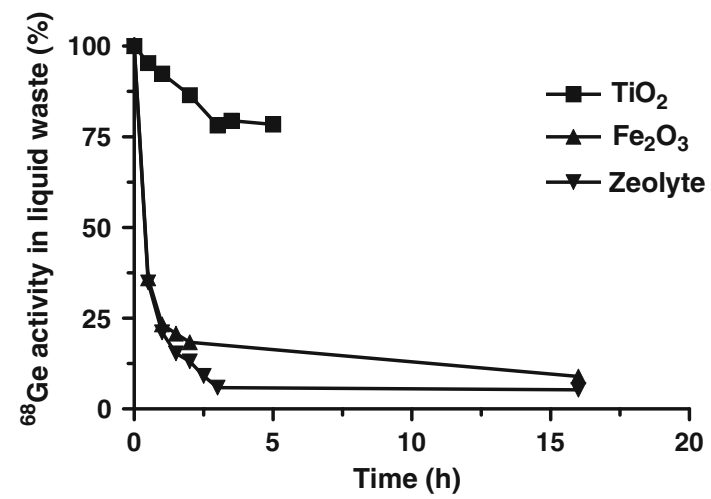

Fig. 6 Recirculation system with ${ }^{68} \mathrm{Ge}$ waste in $1 \mathrm{M} \mathrm{HCl}$. One gram of sorption material was enclosed, see Fig. $1 .{ }^{68} \mathrm{Ge}$ activity was quantified at indicated time points. Zeolite showed optimal sorption of ${ }^{68} \mathrm{Ge}$ activity within $4 \mathrm{~h}(>95 \%)$ 


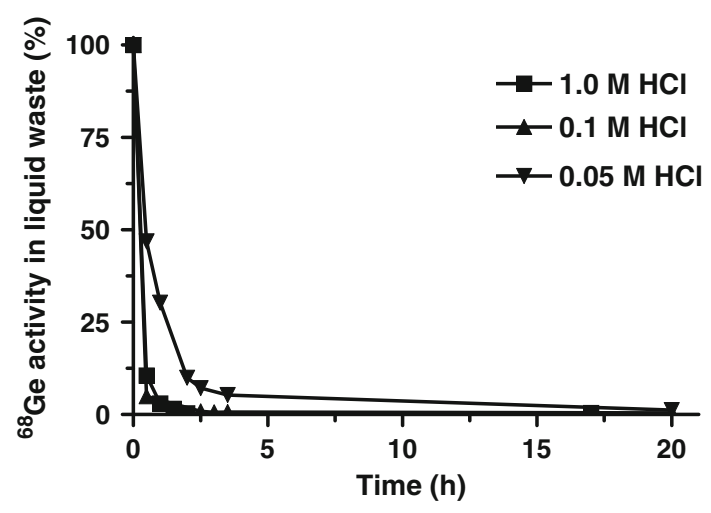

Fig. 7 Since Zeolite showed an optimal sorption of ${ }^{68} \mathrm{Ge}$ activity (Fig. 5), a column containing Zeolite $( \pm 1$ g, Fig. 1) was tested with ${ }^{68} \mathrm{Ge}$ waste in $0.05,0.1$ or $1.0 \mathrm{M} \mathrm{HCl} .{ }^{68} \mathrm{Ge}$ activity was quantified at indicated time points. Recirculation system using higher concentration of $\mathrm{HCl}$ showed high sorption of ${ }^{68} \mathrm{Ge}$ activity at earlier time points

\section{Conclusion}

$\mathrm{TiO}_{2}, \mathrm{Fe}_{2} \mathrm{O}_{3}$ and Zeolite as sorbent, lower ${ }^{68} \mathrm{Ge}$-containing liquid waste down to $10 \mathrm{~Bq} / \mathrm{g}$. Recirculation procedure using Zeolite as sorbent is preferred since less intervention with ${ }^{68} \mathrm{Ge}$ containing liquid waste has to be performed and solid waste mass is reduced.

Acknowledgment The authors wish to thank Timo Kleijn for technical assistance.

Open Access This article is distributed under the terms of the Creative Commons Attribution Noncommercial License which permits any noncommercial use, distribution, and reproduction in any medium, provided the original author(s) and source are credited.

\section{References}

1. Breeman WA, de Jong M, de Blois E, Bernard BF, Konijnenberg M, Krenning EP (2005) Radiolabelling DOTA-peptides with $68 \mathrm{Ga}$. Eur J Nucl Med Mol Imaging 32:478-485

2. Decristoforo C, Knopp R, von Guggenberg E, Rupprich M, Dreger T, Hess A, Virgolini I, Haubner R (2007) A fully automated synthesis for the preparation of $68 \mathrm{Ga}$-labelled peptides. Nucl Med Commun 28:870-875

3. Gebhardt P, Opfermann T, Saluz HP (2010) Computer controlled $68 \mathrm{Ga}$ milking and concentration system. Appl Radiat Isot 68:1057-1059

4. Meyer GJ, Macke H, Schuhmacher J, Knapp WH, Hofmann M (2004) 68 Ga-labelled DOTA-derivatised peptide ligands. Eur J Nucl Med Mol Imaging 31:1097-1104

5. Ocak M, Antretter M, Knopp R, Kunkel F, Petrik M, Bergisadi N, Decristoforo C (2010) Full automation of (68)Ga labelling of DOTA-peptides including cation exchange prepurification. Appl Radiat Isot 68(2):297-302

6. Velikyan I, Beyer GJ, Langstrom B (2004) Microwave-supported preparation of $(68) \mathrm{Ga}$ bioconjugates with high specific radioactivity. Bioconjug Chem 15:554-560

7. Velikyan I, Sundin A, Eriksson B, Lundqvist H, Sorensen J, Bergstrom M, Langstrom B (2010) In vivo binding of [68 Ga]DOTATOC to somatostatin receptors in neuroendocrine tumours-impact of peptide mass. Nucl Med Biol 37:265-275

8. Zhernosekov KP, Filosofov DV, Baum RP, Aschoff P, Bihl H, Razbash AA, Jahn M, Jennewein M, Rosch F (2007) Processing of generator-produced $68 \mathrm{Ga}$ for medical application. J Nucl Med 48:1741-1748 